\title{
An assessment of gender norms of dietary habits at the time of climate change in Chandigarh, India
}

\author{
Suraj Das \\ Department of Humanities and Social Sciences, \\ Indian Institute of Technology (IIT) Roorkee, Roorkee, India
}

\begin{abstract}
Purpose - The purpose of this present paper is twofold: (1) to study the role of gender in food preferences and (2) to study the change in food choice due to climate change in Chandigarh, India. Thus, the hypothesis developed are that (1) there is a significant effect of environmental change on the dietary habits of the women and (2) gender norms are significant in the selection of foods in Chandigarh.

Design/methodology/approach - The literature review was done with the help of NVivo 11, and for quantitative data analysis, SPSS version 22 is used.

Findings - The study concluded that societal gender norms were not significant for women in the choice of food. Also, climate change and women are an essential factor in food preferences at the household level.

Originality/value - While framing the adaptation policy and programs at the institutional level, the cultural and traditional knowledge gets little attention. Hence, the present paper will contribute in the policy-making from a gender perspective.
\end{abstract}

Keywords Society, Gender norms, Climate change, Food choice, NVivo, SPSS

Paper type Research paper

\section{Introduction}

The impact of climatic variabilities such as floods and drought is not gender-neutral but affects women differently (Aguilar, 2013; Reggers, 2019). The very reason for such differential impact is the embedded societal norms that are discriminatory to women in society by default (Prentice and Carranza, 2002; Tait et al., 2019). Further, due to unfavourable gender-defined roles of women, the capacity to adapt gets affected. Therefore, the gender-disaggregated approach needs to be integrated to tackle and in capacity building among the vulnerability of various social groups (Arora-Jonsson, 2011; Morchain et al., 2015). The increase in greenhouse gases leads to increased global temperature due to human activity, known as climate change (Meinshausen et al., 2011; Montzka et al., 2011; Ramanathan and Feng, 2009). Furthermore, rising global temperatures have been linked to glacier melting, changes in the precipitation cycle, melting of ice in the Arctic, ozone layer degradation and ocean acidification (Pingali et al., 2019).

(C) Suraj Das. Published in Ecofeminism and Climate Change. Published by Emerald Publishing Limited. This article is published under the Creative Commons Attribution (CC BY 4.0) licence. Anyone may reproduce, distribute, translate and create derivative works of this article (for both commercial and noncommercial purposes), subject to full attribution to the original publication and authors. The full terms of this licence may be seen at http://creativecommons.org/licences/by/4.0/legalcode

Funding: University Grant Commission (UGC), India.

The authors would like to thank the Department of Humanities and Social Sciences, Indian Institute of Technology (IIT) Roorkee community for providing access to all necessary resources. And special thanks are due to respected editor and anonymous reviewers for their valuable feedbacks and suggestions.

Declaration of ownership: The authors declare that the present article is an original research work.

Ethical clearance: The institution approved this study.

Disclosure statement: The author declares no potential conflict of interest concerning the study's research, authorship and publication.

Assessment of gender norms

Received 4 July 2021 Revised 3 August 2021 Accepted 18 August 2021 
Similarly, according to IPCC usage, climate change can be recognized with the statistical difference in the average and the unpredictability of its properties over a longer period, typically for decades (Cooper et al., 2008; Team et al., 2010; Thompson et al., 2013). Additionally, the variation in the environmental properties is due to natural discrepancy or due to human interference over an extended period (Caminade et al., 2014; Prudhomme et al., 2003). Also, at the World Food Summit in 1996, food security was defined as the availability of nutritious and safe foods that meet the nutritional needs and dietary choices for every person's healthy lifestyle (Borre et al., 2010; Loring and Gerlach, 2009). Additionally, food is socially and economically accessible to people. This definition integrated the three essential concepts of food and nutritional security that are the availability of food, accessibility of food and absorbability of food (Corrigan, 2011; Fanzo, 2014). Hence, the sufficient and adequate production of food alone is an insufficient condition of any country's food security. As a result, one of the top concerns associated with climate change is nutritional security (Chakrabarty, 2016).

The impact of environmental change varies, i.e. the degree of effects depends on multiple factors in a community, namely, age, gender, social group and socioeconomic status (Miller et al., 2003; Van Anders, 2015). Hence, besides gender-sensitive policies for gender equality and women empowerment, technology and financial resources are also significant in addressing the issue associated with climate change (Mbow et al., 2019). The gender perspective is inevitable for a better understanding of the difference in men's and women's adaptation capacities and risk factors due to climate change (Jost et al., 2016; Ngigi et al., 2017; Yaro et al., 2015). Therefore, it is crucial to collect and analyse the sex-disaggregated data with both quantitative and qualitative studies. Also, to study the gender-differentiated impacts due to changing climate and the benefits of gender-specific adaptation practices. Further, agricultural activities are essential to understand men's and women's role in food choices and food security because gender plays a crucial role in producing and processing food (Doss, 2001; Jost et al., 2016; Ragasa et al., 2019).

The Chandigarh region is usually regarded as information deficient due to random, scarce, unreliable and unreachable research work. Although there has been an exponential upsurge of climatic variabilities according to considerable research in the region's recent decades, regionalspecific scientific studies are lacking. The impact of environmental change differs according to the differentiated adaptive capacities of males and females. Further, choices of food have always been associated with social and cultural norms of society. Thus, the primary reasons adding to disparities in the climate change associated perception need to be integrated holistically and comprehensively for an inclusive policy to address the issue of food insecurity in the time of global climate change. Therefore, the current study will be an addition to the literature, i.e. the present research will add the novel dimensions of climate change and gender through the lens of food habits at the households levels in a traditional society.

Additionally, it is important to mark and identify the various strategies to cope with climate risk according to the perception of both men and women associated with food security. Sustainable agricultural practices are influenced by social norms, the individual household and the community's decision-making process (Carrigan et al., 2011; Hoang et al., 2006). Therefore, gender perspectives need to be systematically analysed and addressed while framing the policies and programs to tackle the issue of climate change (Gitz et al.,2016). Therefore, the objective of the study was to (1) document and explore the food preference in times of climate change, (2) understand the culturally defined role of women in Chandigarh, India. Thus, the hypothesis developed are that (1) there is a significant effect of environmental change on the dietary habits of the women and (2) gender norms are significant in the selection of foods in Chandigarh.

\section{Material and methodology \\ Sampling and data collection}

A cross-sectional study was conducted to measure the perception and attitudes towards climate change and women's role in food choices (Nigatu et al., 2014; Xiang et al., 2016). 
The questionnaires were separated into two portions for this study. Section A contained demographic data of the respondents, such as age, gender and marital status, whereas Section B had questions to be researched for the theoretical framework. We measured the responses on a 5 -point Likert scale $(1=$ Strongly Disagree; $2=$ Disagree; $3=$ Neutral; $4=$ Agree; $4=$ Strongly Agree). Additionally, a literature review was also done for a better understanding of the phenomena and in-depth analysis. Further, for the pilot study, 70 respondents were interviewed through random sampling in September/October 2020 at Sectors 11, 12, 14 and near Government Medical College Sector 16 in Chandigarh, India. The time duration for each interview was around $45 \mathrm{~min}$ for the current primary study.

\section{Data analysis}

A thematic approach was used to develop the themes based on the literature with the help of NVivo 11 qualitative data analysis software. Following the research by Das and Mishra (2021), Sechelski and Onwuegbuzie (2019), a combination of keywords was chosen to search the scientific documents related to climate change. The keywords used are (1) climate change; AND (2) gender' AND (3) food choices, OR traditional food, OR dietary habits; AND (4) cultural norms. These keywords were entered into Google Scholar, Web of Science and ScienceDirect to retrieve the related data. Initially, 90 publications were collected. Out of these, some were not relevant, and some data were missing, i.e. unavailability of abstract or no relation to the research topic was excluded, i.e. 25 were excluded. By the end, only 65 documents were incorporated and text mining analysis (Figure 1). Finally, three broad themes were generated: (1) Gender; (2) Climate Change; and (3) Food Choices.

Further, the data were entered into version 22 of the Statistical Product for Service Solution. For the quantitative data analysis, both descriptive (frequency, percentage, mean and standard deviation) and inferential statistics (independent samples $t$-test and correlation analysis) were used to analyse if gender is significant while food preferences during climate change (Ho, 2013; Patel, 2009). The independent samples $t$-test was used to compare two independent groups, such as gender, divided into males and females. The $t$-test was run to explore the variation in male's and female's perceptions associated with gender norms of food choices at the 0.05 statistical significance level.

\section{Results and discussion}

The demographic (gender and age) and lifestyle (marital status) factors are shown in Table 1, which was used for the present study. The number of females was $28(40 \%)$, and male participants were $42(60 \%)$. Similarly, the $25(35.7 \%)$ respondents were married, and 45 $(64.3 \%)$ were unmarried. Also, $35(50 \%)$ respondents were in the age group of 14-23 years, 29 $(41.4 \%)$ were in the $24-33$ years group, $3(4.3 \%)$ in the $34-43$ years group, $2(2.9 \%)$ were in the age group of $44-53$ years and $1(1.4 \%)$ participant was more than 54 years old.

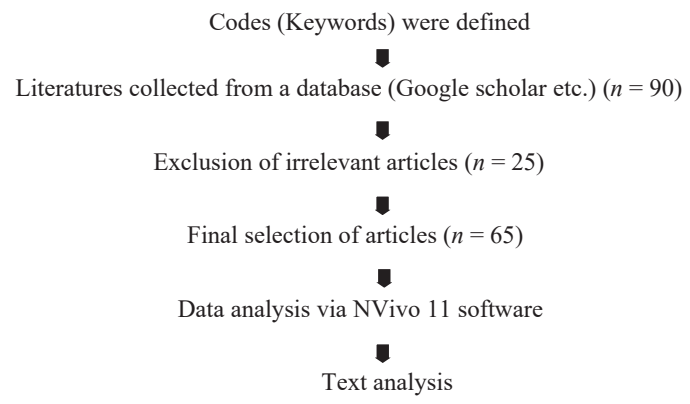

Figure 1. Sampling and data analysis
Assessment of gender norms 


\begin{tabular}{llcrr}
\hline & & Frequency & Percent & Cumulative percent \\
\hline \multirow{2}{*}{ Gender } & Female & 28 & 40.0 & 40.0 \\
& Male & 42 & 60.0 & 100.0 \\
Marital status & Total & 70 & 100.0 & 64.3 \\
& Unmarried & 45 & 64.3 & 100.0 \\
& Married & 25 & 35.7 & 50.0 \\
& Total & 70 & 100.0 & 91.4 \\
& $14-23$ & 35 & 50.0 & 95.7 \\
& $24-33$ & 29 & 41.4 & 98.6 \\
& $34-43$ & 3 & 4.3 & 100.0 \\
& $44-53$ & 2 & 2.9 & \\
& $54+$ & 1 & 1.4 &
\end{tabular}

Table 1.

Demographic (gender and age) and lifestyle (marital status) data
Hypothesis testing: To answer the objectives of the study and to test the significance of the hypothesis, two following null hypotheses were developed:

H1. There is no significant effect of environmental change on the dietary habits of the women in Chandigarh.

Regression analysis was run to determine if there is a significant effect of environmental change on Chandigarh's women's dietary habits. The test was run at a 95\% confidence level, i.e. at a $5 \%$ level of significance. The results are shown in Table 2 . The model summary provides the correlation coefficient and coefficient of determination $\left(R^{2}\right)$ for the regression model. The correlation coefficient $(R)$ value is 0.294 that indicates a weak positive effect of environmental change on the eating choices of women in Chandigarh. The present study's result is in sync with earlier studies (Pingali et al., 2019; Wang et al., 2014) that have observed the significant impact of climatic variabilities on women's dietary habits.

Table 3 shows the ANOVA results to see if the regression model predicts a statistically substantial amount of the variation. It uses a ratio to measure how much the linear regression model estimates the accuracy of simply using the mean of the outcome data as both an estimate. Because the model predicts the results of the analysis, it is statistically significant (if $p=0.04<0.05$ ) despite the modest correlation.

The regression analysis table gives the values for the regression line. The result predicts an increase of 0.055 on the food choice factor for every climate change factor and a decrease of -0.282 on the food choice factor for every woman factor, as shown in Table 4 . From the

\begin{tabular}{|c|c|c|c|c|}
\hline Model & $R$ & $R$ square & Adjusted $R$ square & Std. error of the estimate \\
\hline 1 & $0.294^{\mathrm{a}}$ & 0.086 & 0.059 & 1.087 \\
\hline
\end{tabular}

\begin{tabular}{llccccc}
\hline Model & & Sum of squares & Df & Mean square & $F$ & Sig. \\
\hline 1 & Regression & 7.477 & 2 & 3.738 & 3.162 & $0.049^{\mathrm{b}}$ \\
& Residual & 79.223 & 67 & 1.182 & & \\
& Total & 86.700 & 69 & & &
\end{tabular}

Table 3.

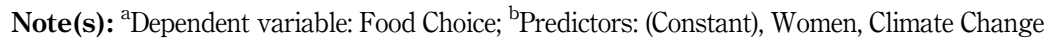


analysis, the study was able to reject the null hypothesis and concludes that at a $95 \%$ confidence level, there is a significant $(p=0.04<0.05)$ influence of climate change and women factors on food choice in Chandigarh.

H2. Women and gender norms are no significant in the selection of foods in Chandigarh.

The second research question investigated the effect of demographic variables (age, gender and marital status) on the choice of traditional food. The influence of gender is presented in Table 2. In Table 5, the independent samples $t$-test shows that statistically there was no significant difference in the attitude and perception of male $(M=4.29$, Std. $\mathrm{D}=0.77)$ and female $(M=4.18$, Std. $\mathrm{D}=1.056)$ for gender norms $[t(68)=-0.49, p>0.05]$. Since the $p$-value was greater than 0.05 , the study was unable to reject the null hypothesis. Hence, the results showed that gender norms did not affect food choices by women in Chandigarh. The result is inconsistent with (Gitz et al., 2016; Mbow et al., 2019; Wardle et al., 2004), who noticed that gender norms are among the significant factors that affect food choice.

\section{Association between gender, climate change and food choices}

Food access is exacerbated in times of climate change due to gender, age, sociocultural norms and economic constraints within a household (Sultana, 2014, 2018). The women are mostly among the disadvantageous group in a family due to the association of inaccurate economic value to the work they perform at household and hence get lesser recognition. The cultural norms and matters related to gender-defined women's role in society further exacerbate poor accessibility (Agrawal and Agrawal, 2010; Lahelma et al., 2002). Therefore, during unforeseen events such as rainfall cloud bursts and rainfall shocks, women of the household have to suffer due to a reduction in food security (Pingali et al., 2019).

Moreover, the food choice is not only about why we eat the foods we do, but the phenomenon is the complex one that involves the power to decide from the abundance of available food options (Chen et al., 2016; Gyimóthy and Mykletun, 2009). Another important aspect is the food chain phases through which the food passes from production, processing, purchasing and preparation to the final act of ingestion (Kathuria and Gill, 2013; Wood and Bruhn, 2000). Also, the preference for food gets influenced by tastes, cultural norms and so forth during climatic changes (Lake et al., 2015).

The global participation rate of women in the agricultural sector is around $43 \%$ of the aggregate working population in the farming sectors and allied activities. Therefore, ensuring gender equality is one of the prominent issues and challenges in the

\begin{tabular}{llrrrrr}
\hline & & \multicolumn{2}{c}{$\begin{array}{c}\text { Unstandardized } \\
\text { coefficients }\end{array}$} & Standardized coefficients & $t$ & Sig. \\
\hline 1 & (Constant) & 4.978 & 0.845 & & 5.894 & 0.000 \\
& Climate change & 0.058 & 0.124 & 0.055 & 0.469 & 0.641 \\
& Women & -0.354 & 0.148 & -0.282 & -2.397 & 0.019
\end{tabular}

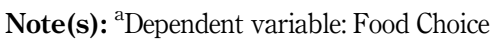

Assessment of gender norms

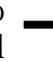


age of climate change for adaptation measures (Meybeck et al., 2018). Considering the genderspecific differences, women and girls are the most vulnerable group exposed to the severe impact of changing climate (Dankelman, 2002; Neumayer and Plümper, 2007). Hence, the need arises for the integration of specific geographical conditions, cultural and socio-economic conditions of the communities (Uns/Scn, 2010). The impact of climate change is visible upon a human in the form of reduced incomes due to sustainable livelihood. Also, cause disruption in trades and negative implications for human health. Besides, it also affects aquaculture, fisheries, crop productivity, livestock, forestry, etc. (Howden et al., 2007; Zougmoré et al., 2016). That results in negative impacts on social and economic activity globally (Chakrabarty, 2016).

In modern times, the loss of culturally relevant subsistence practices such as indigenous and local knowledge has led to the loss of significant adaptive capacities (Pascua et al., 2017; Peloquin and Berkes, 2009). Since the cultural beliefs and values are embedded in local food systems; therefore, indigenous knowledge can be beneficial in increasing the resilience of food stem during climate change (Mbow et al., 2019). Additionally, there is a need for recognition and appreciation of indigenous and locally available food options. Furthermore, due to a lack of awareness of the benefit and sustainability of locally produced food, which is in sync with traditional culture, the younger generation suffers due to nutritional insecurities. As a result, the need arises to integrate both traditional and scientific knowledge of dietary habits (Meybeck et al., 2018).

A case study of women in Singapore observed that due to phenomenal economic growth and improved educational level, the women felt empowered. Further, due to more economic power, women from various ethnicities were able to influence families' food choices (Wang et al., 2014). So women were found significant in the selection of food in a household. Similarly, women's belief in weight control and the notion of healthy eating also influence the choice of food; hence the societal influence also plays a significant role (Manippa et al., 2017; Wardle et al., 2004).

Since, at the climate negotiation forums and national debates, gender concerns are missing institutionally, which results in the allocation of budgets and other financial shares (Biswas, 2004; Nilsson, 2017). Therefore, the analysis should incorporate the vulnerability, adaptation and mitigation factors of high-risk populations, especially women and children. Gender inclusion needs to be supported at the policy formation level related to climate change (Ketrish and Dorozhkin, 2016; O'Connell et al., 2020). Accessibility of sustainable energy sources and water in remote and rural areas needs to be focused on at the local and community level. Besides, capacities to deal with changing climate require the administrations' attention and the local governments to make the community more resilient during emergency situations (Pasquini et al., 2015; Qi et al., 2008). The support of international efforts is needed for the policy formation level to integrate the gender policy to address the issue of environmental change (Narain et al., 2009). The summary of the reviewed literature is shown in Table 6, which summarizes the central idea of select studies in defining the dynamics of core concepts, namely, gender, climate change and food choices.

\section{Conclusions}

The lack of gender-specific data is one of the primary reasons, which prevents policymakers from acknowledging the significance of women's efforts and responsibilities at the household levels in assuring food security. Therefore, the integration of gender-specific data and perspective must be the first objective for women empowerment and further for the recognition of the role of the female in making food security strategies. Therefore, the present study was conducted, and the study observed that women influence the choice of food in the face of changing climate (Bee, 2014; Burke and Lobell, 2010; Kristjanson et al., 2017). Also, it 


\begin{tabular}{|c|c|c|c|}
\hline Categories & Themes & Description & Authors \\
\hline \multirow[t]{6}{*}{ Gender } & $\begin{array}{l}\text { Sociocultural } \\
\text { norms }\end{array}$ & $\begin{array}{l}\text { Gender role is associated with sociocultural } \\
\text { beliefs systems, age and socioeconomic status } \\
\text { affects food choices during climate change }\end{array}$ & Pingali et al. (2019) \\
\hline & Social groups & $\begin{array}{l}\text { Gender, sexual orientation, age, class, ethnicity, } \\
\text { ability/disability and wealth are the factors that } \\
\text { significantly influence the impact of climate } \\
\text { change among various social groups }\end{array}$ & Mbow et al. (2019) \\
\hline & Gender centrality & $\begin{array}{l}\text { Sex-disaggregated data are essential for the sex- } \\
\text { differentiated impact of climatic variabilities } \\
\text { and hence for gender-specific adaptation needs }\end{array}$ & Gitz et al. (2016) \\
\hline & Differential impact & $\begin{array}{l}\text { The effect of climatic variabilities is not gender- } \\
\text { neutral }\end{array}$ & $\begin{array}{l}\text { Narain et al. (2009), } \\
\text { Uns/Scn (2010) }\end{array}$ \\
\hline & $\begin{array}{l}\text { Traditional } \\
\text { knowledge }\end{array}$ & $\begin{array}{l}\text { Traditional, indigenous, and local knowledge of } \\
\text { food should be integrated during the formation } \\
\text { of various adaptation policies }\end{array}$ & Meybeck et al. (2018) \\
\hline & Decision makings & $\begin{array}{l}\text { Due to economic growth, decision-making } \\
\text { power empowered women to make and } \\
\text { influence food choices for the household }\end{array}$ & Wang et al. (2014) \\
\hline \multirow[t]{3}{*}{$\begin{array}{l}\text { Climate } \\
\text { change }\end{array}$} & GHGs & $\begin{array}{l}\text { Climate change refers to the fluctuation in global } \\
\text { temperature due to increased greenhouse gas } \\
\text { emissions and impacts the human being }\end{array}$ & Pingali et al. (2019) \\
\hline & $\begin{array}{l}\text { Human and } \\
\text { natural activities }\end{array}$ & $\begin{array}{l}\text { Environmental changes due to ecological and } \\
\text { human activities }\end{array}$ & $\begin{array}{l}\text { Khan and Hasan } \\
\text { (2017) }\end{array}$ \\
\hline & $\begin{array}{l}\text { Synonyms for } \\
\text { climate change }\end{array}$ & $\begin{array}{l}\text { Global change, global environmental change } \\
\text { and climate change are interchangeably used for } \\
\text { the same phenomena that are climate change }\end{array}$ & $\mathrm{Al}$ et al. (2018) \\
\hline \multirow[t]{3}{*}{ Food choice } & Definition & $\begin{array}{l}\text { Food choice is a complex phenomenon that gets } \\
\text { influenced at every stage, from production, } \\
\text { processing, purchasing and preparation to } \\
\text { ingestion }\end{array}$ & Lake et al. (2015) \\
\hline & Cultural beliefs & $\begin{array}{l}\text { Gendered norms and cultural beliefs in society } \\
\text { are significant for drawing coping strategies }\end{array}$ & Mbow et al. (2019) \\
\hline & Dimensions & $\begin{array}{l}\text { Three main aspects of food security are food } \\
\text { availability, accessibility to food and food } \\
\text { absorption }\end{array}$ & Chakrabarty (2016) \\
\hline
\end{tabular}

\section{Assessment of gender norms}

Gender role is associated with sociocultural beliefs systems, age and socioeconomic status ability/disability and wealth are the factors that significantly influence the impact of climate change among various social groups differentiated impact of climatic variabilities and hence for gender-specific adaptation needs act of climatic variabilities is not genderTraditional, indigenous, and local knowledge of food should be integrated during the formation of various adaptation policies

power empowered women to make and influence food choices for the household temperature due to increased greenhouse gas emissions and impacts the human being human activities

Global change, global environmental change and climate change are interchangeably used for the same phenomena that are climate change influenced at every stage, from production, processing, purchasing and preparation to ingestion are significant for drawing coping strategies Three main aspects of food security are food absorption
Table 6.

Summary of the reviewed literature

has been observed that societal gender norms are not a significant factor for women in their decision-making related to Chandigarh's food choices. That is inconsistent with various studies and societies. This study emphasizes the importance of women in traditional households' food choices in the face of climatic variabilities. Thus, based on the preliminary research results, the stress needs to be laid on gender perspective besides the scientific and technological aspects in addressing food insecurity. There are certain limitations for the current study, i.e. since the preliminary research was conducted with a sample size of 70 participants only, so the study's findings may not be generalized. But, the present study is an indication of the changing dynamic of society.

Therefore, future studies should also integrate other factors like role technology, rationality factors, education level, etc., to get a clear picture with a larger sample size. Thus, the current preliminary research finding can aid in making inclusive and integrative strategies by including sociocultural aspects associated with traditional society's dietary choice norms. Also, the present study can be replicated at the macro level for evidence-based policy planning to tackling the problem of food insecurity, especially at times of climate change. 
Agrawal, P.K. and Agrawal, S. (2010), "To what extent are the indigenous women of Jharkhand, India living in disadvantageous conditions: findings from India's National Family Health Survey 1", Asian Ethnicity, Vol. 11 No. 1, pp. 61-80.

Aguilar, L. (2013), "A path to implementation: gender-responsive climate change strategies", Research, Action and Policy: Addressing the Gendered Impacts of Climate Change, Springer, Dordrecht, pp. 149-157.

Al, W., orking, G. and Clima, O. (2018), "Climate change and food security: a framework document", FAO (Food and Agriculture Organization of the United Nations), Vol. 30 No. 6, p. 428.

Arora-Jonsson, S. (2011), "Virtue and vulnerability: discourses on women, gender and climate change", Global Environmental Change, Vol. 21 No. 2, pp. 744-751.

Bee, B.A. (2014), "'Si no comemos tortilla, no vivimos:' women, climate change, and food security in central Mexico", Agriculture and Human Values, Vol. 31 No. 4, pp. 607-620.

Biswas, A.K. (2004), "Integrated water resources management: a reassessment: a water forum contribution", Water International, Vol. 29 No. 2, pp. 248-256.

Borre, K., Ertle, L. and Graff, M. (2010), "Working to eat: vulnerability, food insecurity, and obesity among migrant and seasonal farmworker families", American Journal of Industrial Medicine, Vol. 53 No. 4, pp. 443-462.

Burke, M. and Lobell, D. (2010), "Food security and adaptation to climate change: what do we know?", Climate Change and Food Security, Vol. 37, pp. 133-153.

Caminade, C., Kovats, S., Rocklov, J., Tompkins, A.M., Morse, A.P., Colón-González, F.J., Stenlund, H., Martens, P. and Lloyd, S.J. (2014), "Impact of climate change on global malaria distribution", Proceedings of the National Academy of Sciences, Vol. 111 No. 9, pp. 3286-3291.

Carrigan, M., Moraes, C. and Leek, S. (2011), "Fostering responsible communities: a community social marketing approach to sustainable living", Journal of Business Ethics, Vol. 100 No. 3, pp. 515-534.

Chakrabarty, M. (2016), Climate Change and Food Security in India, Observer Research Foundation (ORF), New Delhi, Vol. 157, pp. 1-12.

Chen, J., Papies, E.K. and Barsalou, L.W. (2016), "A core eating network and its modulations underlie diverse eating phenomena", Brain and Cognition, Vol. 110, pp. 20-42.

Cooper, P.J.M., Dimes, J., Rao, K.P.C., Shapiro, B., Shiferaw, B. and Twomlow, S. (2008), "Coping better with current climatic variability in the rain-fed farming systems of sub-Saharan Africa: an essential first step in adapting to future climate change?", Agriculture, Ecosystems and Environment, Vol. 126 Nos 1-2, pp. 24-35.

Corrigan, M.P. (2011), "Growing what you eat: developing community gardens in Baltimore, Maryland", Applied Geography, Vol. 31 No. 4, pp. 1232-1241.

Dankelman, I. (2002), "Climate change: learning from gender analysis and women's experiences of organising for sustainable development", Gender and Development, Vol. 10 No. 2, pp. 21-29.

Das, S. and Mishra, A.J. (2021), "Dietary practices and gender dynamics: understanding the role of women", Journal of Ethnic Foods, Vol. 8 No. 1, pp. 1-7.

Doss, C.R. (2001), "Designing agricultural technology for African women farmers: lessons from 25 years of experience", World Development, Vol. 29 No. 12, pp. 2075-2092.

Fanzo, J. (2014), "Strengthening the engagement of food and health systems to improve nutrition security: synthesis and overview of approaches to address malnutrition", Global Food Security, Vol. 3 Nos 3-4, pp. 183-192.

Gitz, V., Meybeck, A., Lipper, L., Young, C. and Braatz, S. (2016), Climate Change and Food Security: Risks and Responses, Food and Agriculture Organization of the United Nations, Rome, doi: 10. 1080/14767058.2017.1347921. 
Gyimóthy, S. and Mykletun, R.J. (2009), "Scary food: commodifying culinary heritage as meal adventures in tourism", Journal of Vacation Marketing, Vol. 15 No. 3, pp. 259-273.

Ho, R. (2013), Handbook of Univariate and Multivariate Data Analysis with IBM SPSS, CRC Press, Florida.

Hoang, L.A., Castella, J.-C. and Novosad, P. (2006), "Social networks and information access: implications for agricultural extension in a rice farming community in northern Vietnam", Agriculture and Human Values, Vol. 23 No. 4, pp. 513-527.

Howden, S.M., Soussana, J.-F., Tubiello, F.N., Chhetri, N., Dunlop, M. and Meinke, H. (2007), “Adapting agriculture to climate change", Proceedings of the National Academy of Sciences, Vol. 104 No. 50, pp. 19691-19696.

Jost, C., Kyazze, F., Naab, J., Neelormi, S., Kinyangi, J., Zougmore, R., Aggarwal, P., Bhatta, G., Chaudhury, M. and Tapio-Bistrom, M.-L. (2016), "Understanding gender dimensions of agriculture and climate change in smallholder farming communities", Climate and Development, Vol. 8 No. 2, pp. 133-144.

Kathuria, L.M. and Gill, P. (2013), "Purchase of branded commodity food products: empirical evidence from India”, British Food Journal, Vol. 115 No. 9, pp. 1255-1280.

Ketrish, E.V. and Dorozhkin, E.M. (2016), "Building of projecting competence among future teachers in the conditions of introduction of inclusive education", International Journal of Environmental and Science Education, Vol. 11 No. 15, pp. 8237-8251.

Khan, A.A. and Hasan, A. (2017), "Climate change: concern for food security in India", IOSR Journal of Humanities and Social Science, Vol. 22 No. 10, p. 52, doi: 10.9790/0837-2210055257.

Kristjanson, P., Bryan, E., Bernier, Q., Twyman, J., Meinzen-Dick, R., Kieran, C., Ringler, C., Jost, C. and Doss, C. (2017), "Addressing gender in agricultural research for development in the face of a changing climate: where are we and where should we be going?", International Journal of Agricultural Sustainability, Vol. 15 No. 5, pp. 482-500.

Lahelma, E., Arber, S., KivelE, K. and Roos, E. (2002), "Multiple roles and health among British and Finnish women: the influence of socioeconomic circumstances", Social Science and Medicine, Vol. 54 No. 5, pp. 727-740.

Lake, I., Abdelhamid, A., Hooper, L., Graham Bentham, P., Boxall, A., Mike Hulme, P., Paul Hunter, P., Nichols, G. and Keith Waldron, P. (2015), "Food and climate change: a review of the effects of climate change on food within the remit of the Food Standards Agency", pp. 1-111, available at: https://www.food.gov.uk/sites/default/files/575-1-1008_X02001_Climate_Change_and_Food_ Report_28_Sept_2010.pdf.

Le, K., and Nguyen, M. (2021), "In-utero Exposure to Rainfall Variability and Early Childhood Health". World Development, 144, 105485.

Manippa, V., Padulo, C., van der Laan, L.N. and Brancucci, A. (2017), "Gender differences in food choice: effects of superior temporal sulcus stimulation", Frontiers in Human Neuroscience, Vol. 11, doi: 10.3389/fnhum.2017.00597.

Mbow, C., Rosenzweig, C., Barioni, L.G., Benton, T.G., Herrero, M., Krishnapillai, M., Liwenga, E., Pradhan, P., Rivera-Ferre, M.G., Sapkota, T., Tubiello, F. and Xu, Y. (2019), "Climate change and land. Chapter 5: food security", IPCC special report Global Warming of 1.5 oC, available at: https://www.ipcc.ch/site/assets/uploads/2019/08/2f.-Chapter-5_FINAL.pdf, pp. 1-200.

Meinshausen, M., Smith, S.J., Calvin, K., Daniel, J.S., Kainuma, M.L.T., Lamarque, J.-F., Matsumoto, K., Montzka, S.A., Raper, S.C.B. and Riahi, K. (2011), "The RCP greenhouse gas concentrations and their extensions from 1765 to 2300", Climatic Change, Vol. 109 No. 1, pp. 213-241.

Meybeck, A., Laval, E., Levesque, R. and Parent, G. (2018), "Food security and nutrition in the age of climate change", in Proceedings of the International Symposium Organized by the Government of Québec in collaboration with FAO.

Miller, S.L., Forest, K.B. and Jurik, N.C. (2003), "Diversity in blue: lesbian and gay police officers in a masculine occupation", Men and Masculinities, Vol. 5 No. 4, pp. 355-385. 
Montzka, S.A., Dlugokencky, E.J. and Butler, J.H. (2011), "Non-CO 2 greenhouse gases and climate change", Nature, Vol. 476 No. 7358, pp. 43-50.

Morchain, D., Prati, G., Kelsey, F. and Ravon, L. (2015), "What if gender became an essential, standard element of vulnerability assessments?", Gender and Development, Vol. 23 No. 3, pp. 481-496.

Narain, S., Ghosh, P., Saxena, N., Parikh, J. and Soni, P. (2009), Climate Change: Perspectives from India, United Nation Development Programme India, New Delhi, November, 72.

Neumayer, E. and PIEmper, T. (2007), "The gendered nature of natural disasters: the impact of catastrophic events on the gender gap in life expectancy, 1981-2002", Annals of the Association of American Geographers, Vol. 97 No. 3, pp. 551-566.

Ngigi, M.W., Mueller, U. and Birner, R. (2017), "Gender differences in climate change adaptation strategies and participation in group-based approaches: an intra-household analysis from rural Kenya", Ecological Economics, Vol. 138, pp. 99-108.

Nigatu, A.S., Asamoah, B.O. and Kloos, H. (2014), "Knowledge and perceptions about the health impact of climate change among health sciences students in Ethiopia: a cross-sectional study", BMC Public Health, Vol. 14 No. 1, pp. 1-10.

Nguyen, M and Le, K. (2021), "The Impacts of Temperature Shocks on Birth Weight in Vietnam", Population and Development Review.

O'Connell, G., Rivera, A. and Viltard, N. (2020), Green Bonds: Finance Against Climate Change?, Academic Year 2019-2020.

Pascua, P., McMillen, H., Ticktin, T., Vaughan, M. and Winter, K.B. (2017), "Beyond services: a process and framework to incorporate cultural, genealogical, place-based, and indigenous relationships in ecosystem service assessments", Ecosystem Services, Vol. 26, pp. 465-475.

Pasquini, L., Ziervogel, G., Cowling, R.M. and Shearing, C. (2015), "What enables local governments to mainstream climate change adaptation? Lessons learned from two municipal case studies in the Western Cape, South Africa", Climate and Development, Vol. 7 No. 1, pp. 60-70.

Patel, P. (2009), "Introduction to quantitative methods", Empirical Law Seminar, Vol. 14, pp. 1-14.

Peloquin, C. and Berkes, F. (2009), "Local knowledge, subsistence harvests, and social-ecological complexity in James Bay", Human Ecology, Vol. 37 No. 5, pp. 533-545.

Pingali, P., Aiyar, A., Abraham, M. and Rahman, A. (2019), Food Systems for a Rising India, 2019th ed.,.

Prentice, D.A. and Carranza, E. (2002), "What women and men should be, shouldn't be, are allowed to be, and don't have to be: the contents of prescriptive gender stereotypes", Psychology of Women Quarterly, Vol. 26 No. 4, pp. 269-281.

Prudhomme, C., Jakob, D. and Svensson, C. (2003), "Uncertainty and climate change impact on the flood regime of small UK catchments", Journal of Hydrology, Vol. 277 Nos 1-2, pp. 1-23.

Qi, Y., Ma, L., Zhang, H. and Li, H. (2008), "Translating a global issue into local priority: china's local government response to climate change", The Journal of Environment and Development, Vol. 17 No. 4, pp. 379-400.

Ragasa, C., Aberman, N.-L. and Mingote, C.A. (2019), "Does providing agricultural and nutrition information to both men and women improve household food security? Evidence from Malawi", Global Food Security, Vol. 20, pp. 45-59.

Ramanathan, V. and Feng, Y. (2009), "Air pollution, greenhouse gases and climate change: global and regional perspectives", Atmospheric Environment, Vol. 43 No. 1, pp. 37-50.

Reggers, A. (2019), "Climate change is not gender neutral: gender inequality, rights and vulnerabilities in Bangladesh", in Confronting Climate Change in Bangladesh, Springer, Cham, pp. 103-118.

Sechelski, A.N. and Onwuegbuzie, A.J. (2019), "A call for enhancing saturation at the qualitative data analysis stage via the use of multiple qualitative data analysis approaches", The Qualitative Report, Vol. 24 No. 4, pp. 795-821. 
Sultana, F. (2014), "Gendering climate change: geographical insights", The Professional Geographer, London, Vol. 66 No. 3, pp. 372-381.

Sultana, F. (2018), "Gender and water in a changing climate: challenges and opportunities", in Water Security across the Gender Divide, Springer, pp. 17-33.

Tait, C.A., Abdillahi, I., Wong, W., Smith-Cannoy, H. and Siddiqi, A. (2019), "Can the health effects of widely-held societal norms be evaluated? An analysis of the United Nations convention on the elimination of all forms of discrimination against women (UN-CEDAW)", BMC Public Health, Vol. 19 No. 1, pp. 1-10.

Team, C.W., Knutti, R., Abramowitz, G., Collins, M., Eyring, V., Gleckler, P.J., Hewitson, B., Mearns, L., Stocker, T. and Dahe, Q. (2010), IPCC Expert Meeting on Assessing and Combining Multi Model Climate Projections, Intergovernal Panel Climate Change, Geneva.

Thompson, R.M., Beardall, J., Beringer, J., Grace, M. and Sardina, P. (2013), "Means and extremes: building variability into community-level climate change experiments", Ecology Letters, Vol. 16 No. 6, pp. 799-806.

Uns/Scn (2021), "The impacts of rainfall shocks on birth weight in Vietnam", Journal of Development Effectiveness, 1-17.

Van Anders, S.M. (2015), "Beyond sexual orientation: integrating gender/sex and diverse sexualities via sexual configurations theory", Archives of Sexual Behavior, Vol. 44 No. 5, pp. 1177-1213.

Wang, M.C., Naidoo, N., Ferzacca, S., Reddy, G. and Van Dam, R.M. (2014), "The role of women in food provision and food choice decision-making in Singapore: a case study", Ecology of Food and Nutrition, Vol. 53 No. 6, doi: 10.1080/03670244.2014.911178.

Wardle, J., Haase, A.M., Steptoe, A., Nillapun, M., Jonwutiwes, K. and Bellisle, F. (2004), "Gender differences in food choice: the contribution of health beliefs and dieting", Annals of Behavioral Medicine, Vol. 27 No. 2, doi: 10.1207/s15324796abm2702_5.

Wood, O.B. and Bruhn, C.M. (2000), "Position of the American dietetic association: food irradiation", Journal of the Academy of Nutrition and Dietetics, Vol. 100 No. 2, p. 246.

Xiang, J., Hansen, A., Pisaniello, D. and Bi, P. (2016), "Workers' perceptions of climate change related extreme heat exposure in South Australia: a cross-sectional survey", BMC Public Health, Vol. 16 No. 1, pp. 1-12.

Yaro, J.A., Teye, J. and Bawakyillenuo, S. (2015), "Local institutions and adaptive capacity to climate change/variability in the northern savannah of Ghana", Climate and Development, Vol. 7 No. 3 , pp. 235-245.

Zougmoré, R., Partey, S., Ouédraogo, M., Omitoyin, B., Thomas, T., Ayantunde, A., Ericksen, P., Said, M. and Jalloh, A. (2016), "Toward climate-smart agriculture in West Africa: a review of climate change impacts, adaptation strategies and policy developments for the livestock, fishery and crop production sectors", Agriculture and Food Security, Vol. 5 No. 1, pp. 1-16.

Corresponding author

Suraj Das can be contacted at: sdas@hs.iitr.ac.in

For instructions on how to order reprints of this article, please visit our website:

www.emeraldgrouppublishing.com/licensing/reprints.htm

Or contact us for further details: permissions@emeraldinsight.com 